\title{
A cysteine protease from the latex of Ficus benjamina has in vitro anthelmintic activity against Haemonchus contortus
}

\author{
Atividade anti-helmíntica in vitro de uma protease cisteínica do látex de Ficus benjamina \\ contra Haemonchus contortus
}

\author{
Ledia Feitosa Wanderley ${ }^{1}$; Alexandra Martins dos Santos Soares ${ }^{1}$; Carolina Rocha e Silva ${ }^{2}$; \\ Isaias Moreira de Figueiredo ${ }^{1}$; Andre Teixeira da Silva Ferreira ${ }^{3}$; Jonas Perales ${ }^{3}$; Handerson Ribeiro de Oliveira Mota ${ }^{4}$; \\ Jose Tadeu Abreu Oliveira ${ }^{4}$; Livio Martins Costa Junior ${ }^{2 *}$

\begin{abstract}
${ }^{1}$ Laboratório de Bioquímica Vegetal, Programa de Engenharia Química, Centro de Ciências Exatas e Tecnológica, Universidade Federal do Maranhão - UFMA, São Luís, MA, Brasil

${ }^{2}$ Laboratório de Controle de Parasitos, Departamento de Patologia, Centro de Ciências Biológicas e da Saúde, Universidade Federal do Maranhão - UFMA, São Luís, MA, Brasil

${ }^{3}$ Laboratório de Toxinologia, Fundação Oswaldo Cruz - FIOCRUZ, Rio de Janeiro, RJ, Brasil

${ }^{4}$ Laboratório de Proteínas de Defesa Vegetal, Departamento de Bioquímica e Biologia Molecular, Universidade Federal do Ceará UFCE, Fortaleza, CE, Brasil
\end{abstract}

Received May 16, 2018

Accepted July 11, 2018

\begin{abstract}
Haemonchus contortus is a gastrointestinal nematode that is responsible for high mortality rates in ruminant herds. The resistance of nematodes to synthetic anthelmintics is widespread and requires a continuous search for new bioactive molecules, such as proteins. The objective of this study was to evaluate the anthelmintic potential of a protease purified from the latex of Ficus benjamina against $H$. contortus. Fresh latex was collected from plants via small incisions in the green stems, the rubber was removed by centrifugation, and the latex protein extract (LPE) was obtained. After LPE fractionation with ammonium sulfate and chromatography of the fraction containing the highest proteolytic activity on CM-cellulose, a cysteine protease $(\mathrm{FbP})$ was purified. $\mathrm{FbP}$ has a molecular mass of approximately $23.97 \mathrm{kDa}$, and its proteolytic activity was stable between $\mathrm{pH} 6.0$ and $\mathrm{pH} 10$ and over a broad temperature range, with optimum activity at $60{ }^{\circ} \mathrm{C}$. FbP inhibited both the development and exsheathment of $H$. contortus larvae, with $50 \%$ effective concentrations of 0.26 and $0.79 \mathrm{mg} / \mathrm{mL}$, respectively. We conclude that this cysteine protease from $F$. benjamina latex with anthelmintic activity against $H$. contortus could be a promising alternative for the development of products for use in parasite control programmes.
\end{abstract}

Keywords: Protease, nematode, cysteine protease, parasite control, small ruminant.

\begin{abstract}
Resumo
Haemonchus contortus é um nematoide gastrintestinal, responsável por altas taxas de mortalidade em rebanhos de pequenos ruminantes. A resistência dos nematoides aos anti-helmínticos sintéticos está generalizada e requer uma busca contínua por novos compostos bioativos, como as proteínas. O objetivo deste trabalho foi avaliar o potencial anti-helmíntico da protease purificada do látex de Ficus benjamina contra H. contortus. O látex fresco foi coletado das plantas por pequenas incisóes nas hastes verdes e o extrato proteico de látex (EPL) foi obtido. Após o fracionamento do EPL com sulfato de amônio e cromatografia da fração contendo a maior atividade proteolítica da CM-Celulose, uma protease cisteínica (FbP) foi purificada. A FbP tem massa molecular de cerca de 23,97 kDa, a atividade proteolítica foi estável entre pH 6,0 e pH 10 e ao longo de uma ampla faixa de temperatura, com atividade ótima a $60{ }^{\circ} \mathrm{C}$. A FbP inibiu tanto o desenvolvimento quanto o desembainhamento das larvas de $H$. contortus, com $50 \%$ de inibição nas concentraçóes de 0,26 e $0,79 \mathrm{mg} / \mathrm{mL}$, respectivamente. Concluímos que esta protease cisteínica do látex de $F$. benjamina, com ação anti-helmíntica contra $H$. contortus, pode ser uma alternativa promissora para o desenvolvimento de produtos a serem utilizados em programas de controle de parasitos.
\end{abstract}

Palavras-chave: Protease, nematoide, protease cisteínica, controle de parasitos, pequenos ruminantes.

\footnotetext{
*Corresponding author: Livio Martins Costa Junior. Laboratório de Controle de Parasitos, Departamento de Patologia, Centro de Ciências Biológicas e da Saúde, Universidade Federal do Maranhão - UFMA, Av. dos Portugueses, 1966, Cidade Universitária do Bacanga, CEP 65080-805, São Luís, MA,

Brasil.e-mail: livio.martins@ufma.br; livioslz@yahoo.com
} 


\section{Introduction}

Haemonchus contortus infection is one of the most important health problems that affects small ruminant productivity worldwide, especially in the tropics and sub-tropics (TAYLOR et al., 2007; LAMBERT et al., 2017). Resistance to synthetic chemical compounds has prompted the development of new treatments and alternative control strategies (PAPADOPOULOS, 2008; CRISTEL et al., 2017). As an alternative, many plant-derived natural compounds have been identified as sources of potential anthelmintic products against $H$. contortus (BEHNKE et al., 2008; SQUIRES et al., 2011; HOSTE et al., 2015; KLONGSIRIWET et al., 2015).

Proteases have been shown to be promising alternatives for nematode control (STEPEK et al., 2015). In plants, proteases are responsible for controlling various biological processes. Proteases from different plant sources present anthelmintic activity against gastrointestinal nematodes, although important aspects regarding the stability of these proteases at different $\mathrm{pH}$ values and temperatures have not been addressed (DOMSALLA \& MELZIG, 2008; LUOGA et al., 2015).

Historically, plant latex, which is rich in proteases, was used to treat worms in humans and dogs (BEHNKE et al., 2008). However, the efficacy of this approach depends on the protease type and the nematode target (STEPEK et al., 2006; STEPEK et al., 2007a,b). The anthelmintic action of cysteine proteases has been evaluated for parasites of different regions of the digestive tract in experiments using small rodent nematode models and Trichuris suis in pigs (STEPEK et al., 2006; STEPEK et al., 2007a,b; BEHNKE et al., 2008; LEVECKE et al., 2014). Ficin is a protease with a molecular mass of approximately $24 \mathrm{kDa}$ that is extracted from plants of the Ficus genus and is member of a group of enzymes that includes papain and bromelain (GAUGHRAN, 2008). Ficus glabrata latex was shown to exhibit anti-helminthic activity against human worms (HANSSON et al., 1986), and the protease ficin is the only active compound that has been identified in the latex.

Ficus benjamina, of the tribe Ficeae in the Moraceae family, is also known as the weeping fig tree. This species is a medicinal plant in Indonesia but is widespread worldwide due to its ornamental value as an indoor plant and its use in the urban afforestation of public spaces (HASTI et al., 2014; MORO et al., 2014). Although $F$. benjamina latex possesses high proteolytic activity, the protease remains poorly understood and has not been purified to homogeneity to date. The purification is indispensable for confidently testing the bioactive properties of a potential molecule. We have developed a protocol for purifying a protease from $F$. benjamina latex to facilitate its characterization and to assess its anthelmintic potential against the $H$. contortus contributing to an alternative, effective, and sustainable agent for the control of this pathogen.

\section{Materials and Methods}

\section{Latex collection in the field and protein extraction}

The latex of $F$. benjamina was obtained from adult plants in São

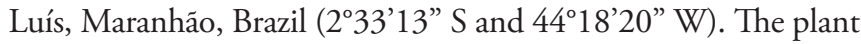
material was deposited in the Herbarium of Maranhão (MAR) of the Federal University of Maranhão, Brazil (registration number 1457). The latex was harvested from incisions made at the apex of the plant branches and collected in a tube containing sodium phosphate buffer $(75 \mathrm{mM}, \mathrm{pH} 7.0)$ in an ice bath. To remove the rubber, the latex was initially centrifuged at $12,000 \times g$ for $15 \mathrm{~min}$ at $4{ }^{\circ} \mathrm{C}$. The supernatant was dialyzed against distilled water (14 kDa cut-off) for $24 \mathrm{~h}$ at $4^{\circ} \mathrm{C}$ and subsequently centrifuged under the same conditions described above. The resulting supernatant was termed latex protein extract (LPE) and maintained at $-20{ }^{\circ} \mathrm{C}$ for subsequent analysis.

\section{Purification of the Ficus benjamina latex protease (FbP)}

LPE was fractionated with ammonium sulfate via sequential precipitation at $0-30 \%(\mathrm{~F} 0-30), 30-60 \%$ (F30-60), and 60-90\% (F60-90). Briefly, in an ice bath with gentle stirring, ammonium sulfate was slowly added to LPE; the suspension was allowed to stand for $12 \mathrm{~h}$ and was then centrifuged at $15,000 \times g$ for $30 \mathrm{~min}$ at $5{ }^{\circ} \mathrm{C}$. The precipitate obtained was resuspended in sodium phosphate buffer (75 mM, pH 7.0) and dialyzed against distilled water (14 kDa cut-off) for two days with five changes per day to remove the ammonium sulfate. The resultant supernatant was used for the next step of salt precipitation.

The ammonium sulfate fraction containing the highest proteolytic activity was applied to an ion exchange column $(2.0 \times 13.0 \mathrm{~cm})$ (CM-cellulose from GE-Healthcare) that was previously equilibrated with sodium acetate buffer ( $50 \mathrm{mM}$; pH 5.2) and eluted at a flow rate of $0.8 \mathrm{~mL} / \mathrm{min}$. The unadsorbed proteins (FNR) were washed out with the equilibration buffer. The bound proteins ( $\mathrm{FbP}$ and F100) were eluted with the above buffer containing $50 \mathrm{mM}$ and $100 \mathrm{mM} \mathrm{NaCl}$, respectively. The samples were dialyzed against distilled water ( $14 \mathrm{kDa}$ cut-off) for $24 \mathrm{~h}$ at $4^{\circ} \mathrm{C}$ with five changes, lyophilized, and stored at $4{ }^{\circ} \mathrm{C}$.

\section{Proteolytic activity assay}

Proteolytic activity was measured as previously described (XAVIER-FILHO et al., 1989), using azocasein as a substrate. Sample aliquots $(0.2 \mathrm{~mL})$ were incubated with $0.3 \mathrm{~mL}$ of sodium phosphate buffer (25 mM, pH 6.0), $0.002 \mathrm{~mL}$ of dithiothreitol (DTT, $1 \mathrm{M}$ ), and $0.2 \mathrm{~mL}$ of azocasein (1\%) for $60 \mathrm{~min}$ at $37{ }^{\circ} \mathrm{C}$. The reaction was stopped by the addition of $0.3 \mathrm{~mL}$ of trichloroacetic acid (TCA, 20\% m/v). The mixture was centrifuged $(10,000 \times g, 10 \mathrm{~min}$, room temperature $)$, and $0.5 \mathrm{~mL}$ of the supernatant obtained was mixed with an equal volume of $\mathrm{NaOH}(2 \mathrm{M})$. The absorbance was read at $420 \mathrm{~nm}$. A variation in absorbance of 0.01 was considered to be a unit of proteolytic activity and was expressed as units of activity per milligram of protein $(\mathrm{AU} / \mathrm{mgP})$. The assays were carried out in triplicate.

\section{Protein content determination}

The protein content was determined following the Bradford (1976) method, using known concentrations of bovine serum albumin (BSA) as the standard. 


\section{Polyacrylamide gel electrophoresis (SDS-PAGE)}

SDS-PAGE was performed according to Laemmli (1970), and protein bands were visualized with silver nitrate (GROMOVA $\&$ CELIS, 2006). In every run, protein molecular mass markers [phosphorylase B $(97 \mathrm{kDa})$, bovine serum albumin $(66 \mathrm{kDa})$, ovalbumin $(45 \mathrm{kDa})$, carbonic anhydrase $(30 \mathrm{kDa})$ and soybean trypsin inhibitor $(20.1 \mathrm{kDa})$ ] were used.

\section{Determination of the optimum $p H$ and temperature for FbP activity}

The optimum $\mathrm{pH}$ was determined at $37^{\circ} \mathrm{C}$ by measuring the proteolytic activity of $\mathrm{FbP}$ at $\mathrm{pH}$ values ranging from 6.0 to 12.0 (azocasein is insoluble at $\mathrm{pH}$ values below 5.0). The following buffer solutions were used at $50 \mathrm{mM}$ concentrations: sodium phosphate ( $\mathrm{pH}$ 6.0); Tris- $\mathrm{HCl}$ ( $\mathrm{pH}$ values 8.0 and 10); and glycine- $\mathrm{NaOH}$ (pH 12) (POST et al., 2012; COÊLHO et al., 2016). The optimum temperature for FbP activity was determined in a temperature range from 10 to $80{ }^{\circ} \mathrm{C}$ under standard assay conditions at $\mathrm{pH}$ 6.0. Three different experiments were performed for both assays.

\section{Molecular mass determination and FbP identification}

The native mass of FbP was carried out according Ponce-Soto et al. (2007) with modifications. Briefly, an FbP aliquot was desalted using C4 ZipTip micro-columns (Millipore), co-crystallized with an alpha-cyano-4-hydroxycinnamic acid matrix, and analysed in a MALDI TOF/TOF 5800 mass spectrometer (AB Sciex, Canada) in positive linear mode. To identify FbP by similarity, reversed-phase nanochromatography coupled with nanoelectrospray high-resolution mass spectrometry was performed after tryptic digestion of the protein. For each sample, $4 \mu \mathrm{L}$ of desalted tryptic peptide digest was initially applied to a 2 -cm-long (100- $\mu \mathrm{m}$ internal diameter) trap column packed with $3 \mu \mathrm{m}$ of 200 A Magic C18 AQ matrix (Michrom Bioresources, USA), followed by separation on a 20 -cm-long $(75-\mu \mathrm{m}$ internal diameter $)$ separation column that was packed with the same matrix directly on an empty self-pack 15- $\mu$ m PicoFrit column (New Objective, USA). Chromatography was carried out on an EASY-nLC II instrument (Thermo Scientific, USA). The samples were loaded onto the trap column at $2000 \mathrm{~nL} / \mathrm{min}$, and chromatographic separation occurred at $200 \mathrm{~nL} / \mathrm{min}$. Mobile phase A consisted of $0.1 \%(\mathrm{v} / \mathrm{v})$ formic acid in water. Mobile phase B consisted of $0.1 \%(\mathrm{v} / \mathrm{v})$ formic acid in acetonitrile. The gradient conditions were as follows: 2 to $40 \%$ B for $168 \mathrm{~min}$ and up to $80 \%$ B for $4 \mathrm{~min}$. This concentration was maintained for 2 additional min before the column was re-equilibrated. The eluted peptides were directly applied to an LTQ XL/Orbi/Trap MS (Thermo, USA) for analysis. The voltage source was set to $1.9 \mathrm{kV}$, the capillary temperature was set to $200{ }^{\circ} \mathrm{C}$, and the tube lens voltage was set to $100 \mathrm{~V}$. The full ion trap value and the MSn AGC target value were 30,000 and 10,000, respectively. The MS1 spectra were acquired on an Orbitrap analyser (300 to $1,700 \mathrm{~m} / \mathrm{z}$ ) at a 60,000 resolution (for $m / z 445.1200$ ). For each spectrum, the 10 most intense ions were subjected to CID fragmentation (minimum signal required of 10,000; isolation width of 2.5; normalized collision energy of 35.0; activation Q of 0.25 and activation time of $30 \mathrm{~s}$ ), followed by MS2 acquisition on a linear trap analyser. The dynamic exclusion option was enabled. The parameter settings were as follows: repeat count $=1$; repeat duration $=30 \mathrm{~s}$; exclusion list size $=500$; exclusion duration $=45 \mathrm{~s}$; and exclusion mass width $=10 \mathrm{ppm}$.

The peptide mass profiles were analysed using Peaks Studio 8.0. Searches were performed using the NCBI and UniProt databases. The search parameters for monoisotopic peptide masses allowed one missed enzymatic cleavage and accepted the carbamidomethylation of cysteine residues and the oxidation of methionine as modifications.

\section{Anthelmintic assays}

Sheep were artificially infected with a monospecific population of $H$. contortus. The experiments were performed in accordance with the guidelines established by the Brazilian College of Animal Experimentation and were approved (23115018061/2011-01 protocol number) by the Ethics Committee for Animal Experimentation of the Federal University of Maranhão, Brazil. H. contortus eggs and larvae were collected in accordance with Coles et al. (1992) and Ueno \& Gonçalves (1998), respectively.

\section{Haemonchus contortus development assay}

The $H$. contortus larval development assay was performed according to Hubert \& Kerboeuf (1992). Approximately 100 eggs were placed in 24-well plates and kept in a controlled environment chamber (BOD, $27{ }^{\circ} \mathrm{C}, \mathrm{RH} \geq 80 \%$ ) for $24 \mathrm{~h}$ to obtain the first-stage larvae $\left(\mathrm{L}_{1}\right)$. Nutritional medium (containing freeze-dried Escherichia coli (ATCC 9637, Sigma), yeast extract, and balanced salt solution from Earle), amphotericin B, and serially diluted protein samples were added to the wells. FbP was solubilized in sodium/potassium phosphate buffer ( $\mathrm{pH} 7.2$ ) containing $125 \mathrm{mM} \mathrm{NaCl}$. This buffer was used as the negative control. Pre-standardized FbP concentrations $(2.0,1.0,0.5,0.25$ and $0.125 \mathrm{mg} / \mathrm{mL})$ were used in quadruplicate. The plates were further incubated $\left(27^{\circ} \mathrm{C}\right.$, $\mathrm{RH} \geq 80 \%$ ), and after 5 days, Lugol's iodine was added to each well to stop larval development. $\mathrm{L}_{1}$ and $\mathrm{L}_{3}$ were counted, and larval development inhibition (\%) was calculated using the following equation: $\mathrm{L}_{3} \times\left(\mathrm{L}_{3}+\mathrm{L}_{1}\right)^{-1} \times(100)$. Efficacy was calculated using the following formula: (the larval development of the negative control [\%]) - (the larval development during FbP treatment $[\%]) \times(\text { negative control development })^{-1} \times(100)$.

\section{Larval exsheathment inhibition assay}

This assay was carried out according to the technique described by Bahuaud et al. (2006). Viable third-stage $\left(\mathrm{L}_{3}\right) H$. contortus larvae were placed in 96-well plates containing $\mathrm{FbP}$ (protein concentrations of $2.0,1.0,0.5,0.25$ and $0.125 \mathrm{mg} / \mathrm{mL}$ ) and incubated in a BOD $\left(27^{\circ} \mathrm{C}, \mathrm{RH} \geq 80 \%\right)$ for $3 \mathrm{~h}$. The larvae were washed three times by centrifugation with distilled water $(2540 \times g, 3 \mathrm{~min})$, and exsheathment was stimulated by the addition of sodium hypochlorite $(2 \%, \mathrm{v} / \mathrm{v})$. The exsheathment process was 
interrupted every $20 \mathrm{~min}$ (up to $60 \mathrm{~min}$ ) by the addition of $10 \mu \mathrm{L}$ of Lugol's iodine. The percentages of larval exsheathment process were monitored by observation under an inverted microscope.

\section{Statistical analysis}

The experiments were performed in triplicate, and the data are expressed as the mean \pm standard deviation. All data were tested by Shapiro-Wilks tests. Biochemical data were compared by one-way ANOVA test using the GraphPad Prism 6.0 at a $5 \%$ significance level. The $50 \%$ effective concentrations $\left(\mathrm{EC}_{50}\right)$ was calculated by probit analysis (LeOra Software Company PoloPlus 2.0) and expressed as the mean and confidence interval (95\%). Values without overlapping confidence intervals were considered significantly different (RODITAKIS et al., 2005).

\section{Results}

\section{Purification of FbP}

Following harvest, the F. benjamina latex, which is a milky material, was processed to remove non-protein components, especially rubber. A translucent sample was obtained and denominated LPE. After LPE fractionation by ammonium sulfate, three protein fractions were obtained: F0-30; F30-60; and F60-90. F0-30 was discarded because it had a low protein recovery (data not shown), whereas F30-60 and F60-90 accounted for approximately 17\% and $62 \%$ of the initial total latex protein content, respectively $(\mathrm{p}=0.02)$ (Table 1$)$.

Proteolytic activity was detected in all tested samples. LPE showed 43,471.1 AU/mgP (Table 1). After ammonium sulfate fractionation of LPE, the F60-90 fraction showed the highest proteolytic activity $(57,857.5 \pm 5,997.4 \mathrm{AU} / \mathrm{mgP})$; therefore, this fraction was further fractionated by ion exchange chromatography on CM-cellulose. Amongst the three fractions obtained (FNR, FbP, and F100) in this step, FbP (abbreviation for Ficus benjamina protease), which was eluted with $50 \mathrm{mM}$ $\mathrm{NaCl}$, had the highest proteolytic activity (Table 1).

After SDS-PAGE, FbP appeared as the main protein band, with an estimated molecular mass of $26.472 \mathrm{kDa}$ (Figure 1), which was close to the $23.972 \mathrm{kDa}$ obtained by mass spectrometry

Table 1. Protein content and proteolytic activity of the protein samples obtained from the latex of Ficus benjamina.

\begin{tabular}{ccc}
\hline Protein sample & $\begin{array}{c}\text { Total protein } \\
(\mathbf{m g})\end{array}$ & $\begin{array}{c}\text { Proteolytic activity } \\
(\mathbf{A U} / \mathbf{m g P})\end{array}$ \\
\hline LPE & $121.6 \pm 4.6^{\mathrm{A}}$ & $43,471.1 \pm 4,760.2^{\mathrm{A}, \mathrm{B}}$ \\
$\mathrm{F} 30-60$ & $21.2 \pm 0.7^{\mathrm{B}}$ & $13,245.9 \pm 3,217.0^{\mathrm{B}}$ \\
F60-90 & $75.7 \pm 1.0^{\mathrm{A}, \mathrm{B}}$ & $57,857.5 \pm 5,997.4^{\mathrm{A}}$ \\
FbP & $1.2 \pm 0.3^{\mathrm{C}}$ & $36,393.8 \pm 6,878.3^{\mathrm{A}, \mathrm{B}}$ \\
\hline
\end{tabular}

Means followed by the different letters in a column differ significantly at $\mathrm{p}<0.01$ by the Tukey test. p value was 0.003. LPE: latex protein extract; F30-60, F60-90\%: fractions obtained by precipitation of LPE at 30-60\% and 60-90\% saturation with ammonium sulfate, respectively; $\mathrm{FbP}$ : F benjamina protease obtained after chromatographic fractionation of F60-90 on CM-Cellulose, eluted with $50 \mathrm{mM} \mathrm{NaCl}$ analysis (data not shown). Moreover, the peptides generated by the tryptic hydrolysis of FbP showed similarity only to plant cysteine proteases (Table 2).

\section{Optimum $\mathrm{pH}$ and temperature and biological activity}

The proteolytic activity of $\mathrm{FbP}$ was stable in the $\mathrm{pH}$ range between 6 and 10 (Figure 2A) after incubation at $37{ }^{\circ} \mathrm{C}$ for $60 \mathrm{~min}$. Although the enzymatic activity was remarkably reduced at $\mathrm{pH} 12$, it remained high $(6,167 \mathrm{AU} / \mathrm{mgP})$. Furthermore, FbP maintained high proteolytic activity in the temperature range between 40 and $70{ }^{\circ} \mathrm{C}$, with the maximum activity reached at $60{ }^{\circ} \mathrm{C}(104,978 \mathrm{AU} / \mathrm{mg} / \mathrm{P})(\mathrm{p} \leq 0.05)$ (Figure $\left.2 \mathrm{~B}\right)$.

\section{Anthelmintic assays}

FbP inhibited the larval development and larval exsheathment of $H$. contortus, with $\mathrm{EC}_{50}$ values of 0.22 (CI 0.212-0.228) and $0.79(0.736-0.853) \mathrm{mg} / \mathrm{mL}$, respectively (Figure 3$)$.

\section{Discussion}

Plant latexes are complex mixtures of important bioactive compounds (AGRAWAL \& KONNO, 2009). In this study, we report for the first time the isolation and partial characterization of a protease from $F$. benjamina latex with characteristics similar

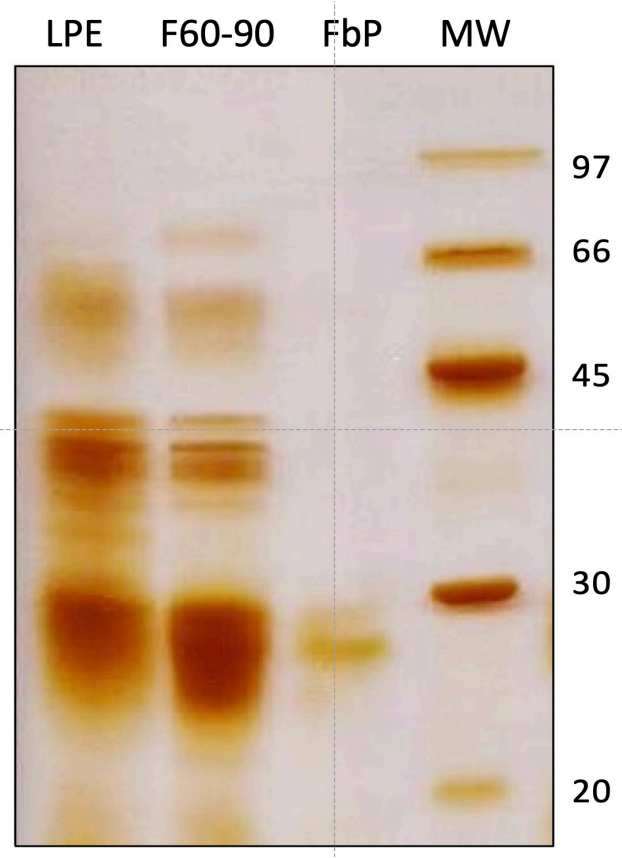

Figure 1. SDS-PAGE (12\%) of the protein fractions from Ficus benjamina latex. LPE: latex protein extract; F60-90: fraction obtained by the precipitation of LPE at $60-90 \%$ saturation with ammonium sulfate; and FbP: Ficus benjamina protease obtained after the chromatographic fractionation of F60-90 on CM-cellulose, eluted with $50 \mathrm{mM} \mathrm{NaCl}$. MW: Molecular-weight size marker. 
Table 2. Similarity of FbP to other plant cysteine proteases.

\begin{tabular}{|c|c|c|c|}
\hline Accession $^{a}$ & $\begin{array}{c}\text { Coverage } \\
(\%)^{\mathrm{b}}\end{array}$ & $\begin{array}{c}\text { Avg. Mass } \\
\text { (kDa) }^{c}\end{array}$ & Description \\
\hline - & - & 23.972 & FbP - Ficus benjamina Protease \\
\hline gi|186516984 & 7 & 41.639 & $\begin{array}{l}\text { Cysteine proteinase } 1 \text { Arabidopsis thaliana] } \text { gi|15290508|gb|AAK92229.1| cysteine } \\
\text { proteinase }[\text { Arabidopsis thaliana] gi|332661313|gb|AEE86713.1| cysteine proteinase } 1 \\
\text { [Arabidopsis thaliana }]\end{array}$ \\
\hline gi|297802228 & 7 & 41.547 & $\begin{array}{l}\text { Cysteine proteinase [Arabidopsis lyrata subsp. lyrata] gi|297314834|gb|EFH45257.1| } \\
\text { cysteine proteinase [Arabidopsis lyrata subsp. lyrata] }\end{array}$ \\
\hline gi|587864551 & 6 & 39.860 & Germination-specific cysteine protease 1 [Morus notabilis] \\
\hline gi|470105671 & 5 & 42.599 & Predicted: cysteine proteinase RD21a-like, partial [Fragaria vesca subsp. vesca] \\
\hline gi|422001787 & 15 & 25.524 & Germination-specific cysteine protease 1, partial [Raphanus sativus] \\
\hline gi|2511689 & 3 & 40.474 & Cysteine proteinase precursor [Phaseolus vulgaris] \\
\hline
\end{tabular}

FbP: F benjamina protease obtained after chromatographic fractionation of F60-90 on CM-Cellulose, eluted with $50 \mathrm{mM} \mathrm{NaCl}$; ${ }^{\mathrm{NCBI}}$ access code; ${ }^{\mathrm{b}}$ the percentage of the protein sequence covered by identified peptides; 'Average mass in $\mathrm{kDa}$ (Avg. Mass).

A

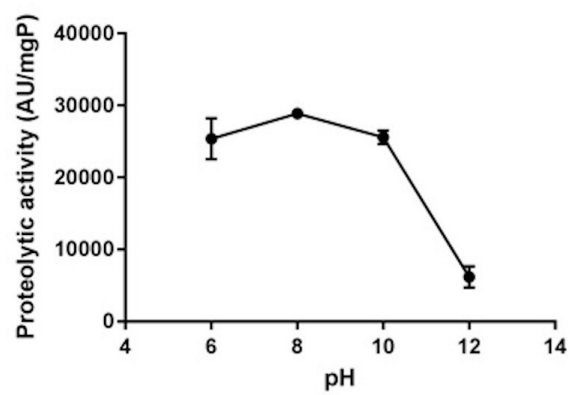

B

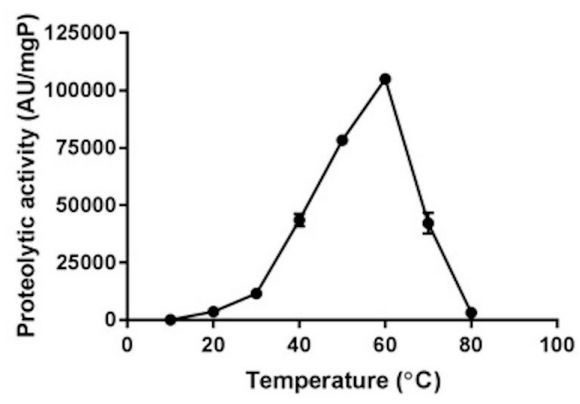

Figure 2. Determination of the optimum $\mathrm{pH}(\mathrm{A})$ and temperature (B) for $\mathrm{FbP}$ activity. The $\mathrm{pH}$ assay was performed at $37^{\circ} \mathrm{C}$ using the following buffers at $50 \mathrm{mM}$ concentrations: sodium phosphate ( $\mathrm{pH}$ 6.0); Tris- $\mathrm{HCl}$ ( $\mathrm{pH} 8.0$ and 10); and glycine- $\mathrm{NaOH}$ ( $\mathrm{pH}$ 12). The ideal temperature was determined by assays conducted at temperatures ranging from 10 to $80{ }^{\circ} \mathrm{C}$ at the $\mathrm{pH}$ of the standard test ( $\mathrm{pH} 6.0$ ).

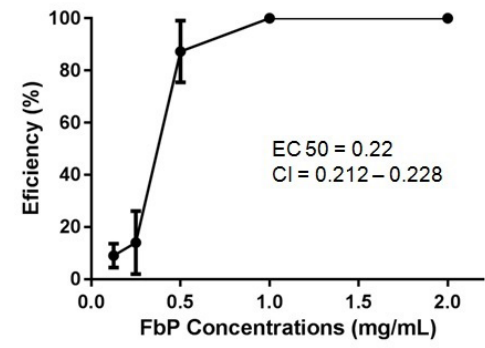

B

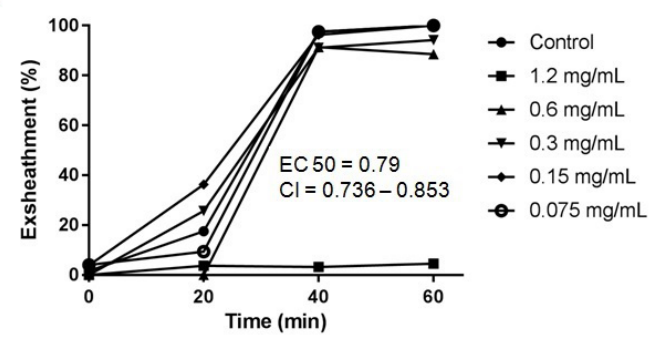

Figure 3. Efficiency ( $\% \pm$ standard deviation) of $\mathrm{FbP}$ in inhibiting the larval development (A) and exsheathment (B) of Haemonchus contortus after treatment with different $\mathrm{FbP}$ concentrations. $\mathrm{EC}_{50}$ : effective concentration (the dose required to achieve a $50 \%$ response); CI: confidence interval (95\%). FbP: Ficus benjamina protease obtained after the chromatographic fractionation of F60-90 on CM-cellulose, eluted with $50 \mathrm{mM} \mathrm{NaCl}$. to those of ficin. Proteases have previously been purified from latexes of other species of the genus Ficus, such as the serine protease of $F$ religiosa, the aspartic protease of $F$. racemosa, the serine collagenolytic protease of $F$. carica, various ficins and cysteine proteases from $F$. carica, and a new ficin from $F$. johannis (DEVARAJ et al., 2008; KUMARI et al., 2010; RASKOVIC et al., 2014; BAEYENS-VOLANT et al., 2015; HOMAEI et al., 2017). Proteases are enzymes that play a variety of physiological and defence roles in plants (SCHALLER, 2004). These enzymes act as control agents for herbivorous insects (MOHAN et al., 2006) and present nematicidal potential against several parasitic nematodes of animals that inhabit different regions of the digestive tract (ROBBINS, 1930; BERGER \& ASENJO, 1940; BEHNKE et al., 2008).

FbP was identified by spectrometry as a cysteine protease of $23.972 \mathrm{kDa}$. Other plant proteases have similar molecular weights, such as those purified from $F$. carica latex $(24.29 \mathrm{kDa})$ (BAEYENS-VOLANT et al., 2015), F. johannis latex $(25 \mathrm{kDa})$ (HOMAEI et al., 2017), and Pergularia extensa latex $(23.35 \mathrm{kDa})$ (SHIVAPRASAD et al., 2010). Moreover, FbP displays protease activity at a broad range of $\mathrm{pH}$ values (6-10) and temperatures (Figure 2). The high activity of the cysteine protease isolated from the latex of Ficus microcarpa at higher temperatures was previously described. The purified enzyme showed maximum activity at $70{ }^{\circ} \mathrm{C}$ (MNIF et al., 2015). Regarding pH stability, 
FbP could remain active in the abomasum of ruminants, which is the $H$. contortus habitat. The abomasum corresponds to the glandular stomach of ruminants; under normal conditions, the abomasum has an acidic $\mathrm{pH}(2-3)$, but $H$. contortus infection can raise the abomasal $\mathrm{pH}$ to values close to neutral (6-7) (NICHOLLS \& LEE, 1989; BUTTLE et al., 2011), which is the optimal range of FbP performance (Figure 2A). Moreover, $\mathrm{FbP}$ has the potential to display anthelmintic activity against other nematodes. These characteristics should be taken into account during the development of new anthelmintic products.

Previous in vitro and in vivo experiments demonstrated the efficient action of proteases against adult gastrointestinal nematodes (BUTTLE et al., 2011; STEPEK et al., 2006; STEPEK et al., 2007a,b; LEVECKE et al., 2014). Similarly, FbP had inhibitory effects on the development and exsheathment of $H$. contortus larvae, with $\mathrm{EC}_{50}$ values of 0.22 and $0.79 \mathrm{mg} / \mathrm{mL}$, respectively (Figure 3). Hydrolysis of the peptide bonds of proteins may be responsible for the anthelmintic properties of the cysteine protease FbP. This assumption is based on previous microscopic observations that cysteine proteases from several plant species act on the protective cuticle of adult nematodes, degrading this structure and rendering it weak enough to be ruptured under the internal hydrostatic pressure of the parasite (STEPEK et al., 2006; STEPEK et al., 2007a,b). For instance, the oral administration of $C$. papaya latex in pigs reduced the $T$. suis load, with an efficiency similar to those of some commercial anthelmintics (LEVECKE et al., 2014). Similar treatment of infected sheep efficiently controlled $H$. contortus (abomasum habitat) but not Trichostrongylus colubriformis (small intestine habitat), possibly due to the physiologic characteristics of the habitat organ and the location of this parasite, which has part of its body inserted in the mucosa. In this latter case, the enzyme must be in contact with the cuticle to exert any deleterious effects (BUTTLE et al., 2011). In the abovementioned studies, the nematicidal efficiency of the latex was attributed to the presence of cysteine proteases. Blocking the anthelmintic action of latex in vitro via the use of cysteine protease inhibitors reinforces the hypothesis that proteases are the active components (STEPEK et al., 2007a,b).

In conclusion, we present herein a cysteine protease that interferes with the development and exsheathment of larvae of the gastrointestinal nematode $H$. contortus. Further studies are needed to assess the mechanism of action of this protease and to develop formulations that aim to increase proteolytic activity under the $\mathrm{pH}$ and temperature conditions of the abomasum and to increase enzyme stability. Nevertheless, FbP is a potential alternative for the development of products for use in control programmes for $H$. contortus in place as a coadjuvant for currently used drugs.

\section{Acknowledgements}

We thank the CNPq (The Brazilian National Council for Scientific and Technological Development) and FAPEMA (Maranhão State Research Foundation) for financial support and the Technology Platform Network from FIOCRUZ, Brazil for facilities support. We also thank CAPES, CNPq and FAPEMA for awarding scholarships to Wanderley, LF, Figueiredo, IM, and Silva, $\mathrm{CR}$, and CNPq for awarding a fellowship to Costa-Junior, LM.

\section{References}

Agrawal AA, Konno K. Latex: a model for understanding mechanisms, ecology, and evolution of plant defense against herbivory. Annu Rev Ecol Evol Syst 2009; 40(1): 311-331. http://dx.doi.org/10.1146/annurev. ecolsys.110308.120307.

Baeyens-Volant D, Matagne A, El Mahyaoui R, Wattiez R, Azarkan M. A novel form of ficin from Ficus carica latex: Purification and characterization. Phytochemistry 2015; 117: 154-167. http://dx.doi. org/10.1016/j.phytochem.2015.05.019. PMid:26083455.

Bahuaud D, Montellano CMO, Chauveau S, Prevot F, Torres-Acosta F, Fouraste I, et al. Effects of four tanniferous plant extracts on the in vitro exsheathment of third-stage larvae of parasitic nematodes. Parasitology 2006; 132(4): 545-554. http://dx.doi.org/10.1017/S0031182005009509. PMid:16388690.

Behnke JM, Buttle DJ, Stepek G, Lowe A, Duce IR. Developing novel anthelmintics from plant cysteine proteinases. Parasit Vectors 2008; 1(1): 29. http://dx.doi.org/10.1186/1756-3305-1-29. PMid:18761736.

Berger J, Asenjo CF. Anthelmintic activity of crystalline papain. Science 1940; 91(2364):387-388. http://dx.doi.org/10.1126/science.91.2364.387. PMid:17773432.

Bradford MM. A rapid and sensitive method for the quantitation of microgram quantities of protein utilizing the principle of proteindye binding. Anal Biochem 1976; 72(1-2): 248-254. http://dx.doi. org/10.1016/0003-2697(76)90527-3. PMid:942051.

Buttle DJ, Behnke JM, Bartley Y, Elsheikha HM, Bartley DJ, Garnett $\mathrm{MC}$, et al. Oral dosing with papaya latex is an effective anthelmintic treatment for sheep infected with Haemonchus contortus. Parasit Vectors 2011; 4(1): 36. http://dx.doi.org/10.1186/1756-3305-4-36. PMid:21406090.

Coêlho DF, Saturnino TP, Fernandes FF, Mazzola PG, Silveira E, Tambourgi EB. Azocasein substrate for determination of proteolytic activity: reexamining a traditional method using bromelain samples. BioMed Res Int 2016; 2016: 8409183. http://dx.doi.org/10.1155/2016/8409183. PMid:26925415.

Coles GC, Bauer C, Borgsteede FHM, Geerts S, Klei TR, Taylor MA, et al. World Association for the Advancement of Veterinary Parasitology (W.A.A.V.P.) methods for the detection of anthelmintic resistance in nematodes of veterinary importance. Vet Parasitol 1992; 44(1-2): 35-44. http://dx.doi.org/10.1016/0304-4017(92)90141-U. PMid:1441190.

Cristel S, Fiel C, Anziani O, Descarga C, Cetrá B, Romero J, et al. Anthelmintic resistance in grazing beef cattle in central and northeastern areas of Argentina - an update. Vet Parasitol Reg Stud Reports 2017; 9: 25-28. http://dx.doi.org/10.1016/j.vprsr.2017.04.003.

Devaraj KB, Gowda LR, Prakash V. An unusual thermostable aspartic protease from the latex of Ficus racemosa (L.). Phytochemistry 2008; 69(3): 647-655. http://dx.doi.org/10.1016/j.phytochem.2007.09.003. PMid:17936863.

Domsalla A, Melzig MF. Occurrence and properties of proteases in plant latices. Planta Med 2008; 74(7): 699-711. http://dx.doi. org/10.1055/s-2008-1074530. PMid:18496785. 
Gaughran ERL. Ficin: history and present status. QJ Crude Drug Res 2008; 14(1): 1-21. http://dx.doi.org/10.3109/13880207609081900.

Gromova I, Celis JE. Protein detection in gels by silver staining: a procedure compatible with mass spectrometry. In: Celis JE, editor. Cell biology. 3rd ed. Cambridge: Academic Press; 2006. p. 219-223. (A Laboratory Handbook; vol. 4). https://doi.org/10.1016/B978-012164730-8/50212-4.

Hansson A, Veliz G, Naquira C, Amren M, Arroyo M, Arevalo G. Preclinical and clinical studies with latex from Ficus glabrata HBK, a traditional intestinal anthelminthic in the Amazonian area. J Ethnopharmacol 1986; 17(2): 105-138. http://dx.doi.org/10.1016/0378-8741(86)90053-X. PMid:3796016.

Hasti S, Mora E, Utami R, Yulis LU. Sub-chronic Toxicity of Ficus Benjamina L. Leaves Ethanol Extract on the Liver Function of White Mice. Procedia Chem 2014; 13: 204-208. http://dx.doi.org/10.1016/j. proche.2014.12.028.

Homaei A, Stevanato R, Etemadipour R, Hemmati R. Purification, catalytic, kinetic and thermodynamic characteristics of a novel ficin from Ficus johannis. Biocatal Agric Biotechnol 2017; 10: 360-366. http://dx.doi. org/10.1016/j.bcab.2017.04.008.

Hoste H, Torres-Acosta JFJ, Sandoval-Castro CA, Mueller-Harvey I, Sotiraki S, Louvandini H, et al. Tannin containing legumes as a model for nutraceuticals against digestive parasites in livestock. Vet Parasitol 2015; 212(1-2): 5-17. http://dx.doi.org/10.1016/j.vetpar.2015.06.026. PMid:26190131.

Hubert J, Kerboeuf D. A microlarval development assay for the detection of anthelmintic resistance in sheep nematodes. Vet Rec 1992; 130(20): 442-446. http://dx.doi.org/10.1136/vr.130.20.442. PMid:1621342.

Klongsiriwet C, Quijada J, Williams AR, Mueller-Harvey I, Williamson EM, Hoste H. Synergistic inhibition of Haemonchus contortus exsheathment by flavonoid monomers and condensed tannins. Int J Parasitol Drugs Drug Resist 2015; 5(3): 127-134. http://dx.doi.org/10.1016/j.ijpddr.2015.06.001. PMid:26199861.

Kumari M, Sharma A, Jagannadham MV. Decolorization of crude latex by activated charcoal, purification and physico-chemical characterization of religiosin, a milk-clotting serine protease from the latex of Ficus religiosa. J Agric Food Chem 2010; 58(13): 8027-8034. http://dx.doi.org/10.1021/ jf101020u. PMid:20560603.

Laemmli UK. Cleavage of structural proteins during the assembly of the head of bacteriophage T4. Nature 1970; 227(5259): 680-685. http:// dx.doi.org/10.1038/227680a0. PMid:5432063.

Lambert SM, Nishi SM, Mendonça LR, Souza BMPS, Julião FS, Gusmão PS, et al. Genotypic profile of benzimidazole resistance associated with SNP F167Y and F200Y beta-tubulin gene in Brazilian populations of Haemonchus contortus of goats. Vet Parasitol Reg Stud Reports 2017; 8: 28-34. http://dx.doi.org/10.1016/j.vprsr.2017.01.006.

Levecke B, Buttle DJ, Behnke JM, Duce IR, Vercruysse J. Cysteine proteinases from papaya (Carica papaya) in the treatment of experimental Trichuris suis infection in pigs: two randomized controlled trials. Parasit Vectors 2014; 7(1): 255. http://dx.doi.org/10.1186/1756-3305-7-255. PMid:24886388.

Luoga W, Mansur F, Lowe A, Duce IR, Buttle DJ, Behnke JM. Factors affecting the anthelmintic efficacy of papaya latex in vivo: host sex and intensity of infection. Parasitol Res 2015; 114(7): 2535-2541. http:// dx.doi.org/10.1007/s00436-015-4456-5. PMid:25855350.

Mnif IH, Siala R, Nasri R, Mhamdi S, Nasri M, Kamoun AS. A cysteine protease isolated from the latex of Ficus microcarpa: purification and biochemical characterization. Appl Biochem Biotechnol 2015; 175(3): 17321744. http://dx.doi.org/10.1007/s12010-014-1376-2. PMid:25424283.

Mohan S, Ma PWK, Pechan T, Bassford ER, Williams WP, Luthe DS. Degradation of the $S$. frugiperda peritrophic matrix by an inducible maize cysteine protease. J Insect Physiol 2006; 52(1): 21-28. http://dx.doi. org/10.1016/j.jinsphys.2005.08.011. PMid:16243350.

Moro MF, Westerkamp C, Araújo FS. How much importance is given to native plants in cities' treescape? A case study in Fortaleza, Brazil. Urban Urban Green 2014; 13(2): 365-374. http://dx.doi.org/10.1016/j. ufug.2014.01.005.

Nicholls CD, Lee DL. Post-mortem changes in the abomasal mucosae of sheep infected with Haemonchus contortus compared with those in uninfected sheep. J Comp Pathol 1989; 100(1): 19-25. http://dx.doi. org/10.1016/0021-9975(89)90086-8. PMid:2918107.

Papadopoulos E. Anthelmintic resistance in sheep nematodes. Small Rumin Res 2008; 76(1-2): 99-103. http://dx.doi.org/10.1016/j. smallrumres.2007.12.012.

Ponce-Soto LA, Bonfim VL, Novello JC, Navarro-Oviedo R, YarlequéChocas A, Marangoni S. Isolation and Characterization of a Serine Protease, Ba III-4, from Peruvian Bothrops atrox venom. Protein J 2007; 26(6): 387394. http://dx.doi.org/10.1007/s10930-007-9078-z. PMid:17522968.

Post AE, Arnold B, Weiss J, Hinrichs J. Effect of temperature and pH on the solubility of caseins: environmental influences on the dissociation of $\alpha(S)$ - and $\beta$-casein. J Dairy Sci 2012; 95(4): 1603-1616. http://dx.doi. org/10.3168/jds.2011-4641. PMid:22459808.

Raskovic B, Bozovic O, Prodanovic R, Niketic V, Polovic N. Identification, purification and characterization of a novel collagenolytic serine protease from fig (Ficus carica var. Brown Turkey) latex. J Biosci Bioeng 2014; 118(6): 622-627. http://dx.doi.org/10.1016/j.jbiosc.2014.05.020. PMid:24982021.

Robbins B. A Proteolytic Enzyme in Ficin, the Anthelmintic Principle of Leche de Higueron. J Biol Chem 1930; 87: 251-257.

Roditakis E, Roditakis NE, Tsagkarakou A. Insecticide resistance in Bemisia tabaci (Homoptera: Aleyrodidae) populations from Crete. Pest Manag Sci 2005; 61(6): 577-582. http://dx.doi.org/10.1002/ps.1029. PMid:15712366.

Schaller A. A cut above the rest: the regulatory function of plant proteases. Planta 2004; 220(2): 183-197. http://dx.doi.org/10.1007/s00425-0041407-2. PMid:15517349.

Shivaprasad HV, Rajaiah R, Frey BM, Frey FJ, Vishwanath BS. 'Pergularain e I' - a plant cysteine protease with thrombin-like activity from Pergularia extensa latex. Thromb Res 2010; 125(3): e100-e105. http://dx.doi. org/10.1016/j.thromres.2009.10.002. PMid:19853890.

Squires JM, Ferreira JFS, Lindsay DS, Zajac AM. Effects of artemisinin and Artemisia extracts on Haemonchus contortus in gerbils (Meriones unguiculatus). Vet Parasitol 2011; 175(1-2): 103-108. http://dx.doi. org/10.1016/j.vetpar.2010.09.011. PMid:20943323.

Stepek G, Lowe AE, Buttle DJ, Duce IR, Behnke JM. In vitro and in vivo anthelmintic efficacy of plant cysteine proteinases against the rodent gastrointestinal nematode, Trichuris muris. Parasitology 2006; 132(5): 681689. http://dx.doi.org/10.1017/S003118200500973X. PMid:16448585.

Stepek G, Lowe AE, Buttle DJ, Duce IR, Behnke JM. Anthelmintic action of plant cysteine proteinases against the rodent stomach nematode, Protospirura muricola, in vitro and in vivo. Parasitology 2007a; 134(1): 103112. http://dx.doi.org/10.1017/S0031182006001302. PMid:17032468. 
Stepek G, Lowe AE, Buttle DJ, Duce IR, Behnke JM. The anthelmintic efficacy of plant-derived cysteine proteinases against the rodent gastrointestinal nematode, Heligmosomoides polygyrus, in vivo. Parasitology 2007b; 134(10): 1409-1419. http://dx.doi.org/10.1017/S0031182007002867. PMid:17475089.

Stepek G, McCormack G, Winter AD, Page AP. A highly conserved, inhibitable astacin metalloprotease from Teladorsagia circumcincta is required for cuticle formation and nematode development. Int J Parasitol 2015; 45(5): 345-355. http://dx.doi.org/10.1016/j.ijpara.2015.01.004. PMid:25736599.
Taylor MA, Coop RL, Wall R. Veterinary parasitology. 4th ed. Hoboken: Wiley-Blackwell; 2007. Parasites of sheep and goats; p. 152-165.

Ueno H, Gonçalves PC. Manual para diagnóstico das helmintoses de ruminantes. Tokyo: Japan International Cooperation Agency; 1998.

Xavier-Filho J, Campos FAP, Ary MB, Silva CP, Carvalho MMM, Macedo MLR, et al. Poor correlation between the levels of proteinase inhibitors found in seeds of different cultivars of cowpea (Vigna unguiculata) and the resistance/susceptibility to predation by Callosobruchus maculatus. J Agric Food Chem 1989; 37(4): 1139-1143. http://dx.doi.org/10.1021/ jf00088a071. 